\title{
Aglaonema 'Golden Bay'
}

\section{R.J. Henny and J. Chen \\ University of Florida, Institute of Food and Agricultural Science, Mid-Florida Research and Education Center, 2725 Binion Road, Apopka, FL 32703}

Additional index words. Aglaonema commutatum, Aglaonema nitidum, Chinese evergreen, foliage plant, plant breeding

The genus Aglaonema (family Araceae), commonly called Chinese evergreen, contains many cultivars that are important ornamental tropical foliage plants due to their tolerance of low light and low relative humidity levels under interior conditions. Historically, most new Aglaonema cultivars were introduced directly from the wild or were selected sports from established cultivars. Control of Aglaonema flowering and development of pollination techniques has led to the production of many new cultivars in the past ten years by both public and private breeders (Henny, 1983, 1985). Aglaonema 'Golden Bay' is one such hybrid developed in the foliage plant breeding program of the Florida Agricultural Experiment Station at the Mid-Florida Research and Education Center (MREC)-Apopka.

\section{Origin}

Aglaonema 'Golden Bay' originated from the cross of two interspecific hybrids (MREC 277028 and 1501), both of which had $A$. commutatum Schott. 'Tricolor' as one parent (Fig. 1). The other parent of MREC 277028 was A. nitidum Kunth 'Ernesto's Favorite'. Aglaonema 'Manila' was used to generate MREC 1501. MREC 1501 has a foliar variegation pattern genotype of $\mathrm{V}^{\mathrm{mn}} \mathrm{V}^{\mathrm{tt}}$ (Henny, 1986) displayed in leaves that ranged from 7 to $9 \mathrm{~cm}$ in width and 21 to $23 \mathrm{~cm}$ in length. Aglaonema hybrid MREC 277028 had leaves with a maximum width of 10 to $12 \mathrm{~cm}$ and length of 32 to $35 \mathrm{~cm}$ along with a leaf variegation pattern genotype of $\mathrm{V}^{\mathrm{mn}} \mathrm{V}^{\text {ef }}$.

\section{Description}

'Golden Bay' has been patented (U.S. Plant Patent No. PP010140). Mature 'Golden Bay' leaves are lanceolate 9 to $10 \mathrm{~cm}$ wide and 28 to $30 \mathrm{~cm}$ long (Fig. 2). 'Golden Bay' branches to produce three to six basal shoots per single stem cutting. Leaves have a green-white (RHS 160CD) midrib and exhibit a central grey-green (RHS 0191A-B) area that extends out from each side of the midrib to cover slightly over half of the total leaf surface (Royal Horticultural Society, 1995). Leaf margins are green (RHS 139A) and intersect the lighter gray-

Received for publication 7 Sept. 2000. Accepted for publication 3 Jan. 2001. Florida Agricultural Experiment Station Journal Series No. R- 07897. The cost of publishing this paper was defrayed in part by the payment of page charges. Under postal regulations, this paper therefore must be hereby marked advertisement solely to indicate this fact.
green(RHS 191A-B) colored central area along irregular borders that often overlap to create small distinct patches of a third color that is a darker gray-green (RHS 189A). These distinct phenotypic leaf variegation patterns are due to the genotype $\mathrm{V}^{\mathrm{mn}} \mathrm{V}^{\mathrm{ef}}$ that produces leaves with two variegation patterns superimposed on each other (Henny, 1986). The overlapping areas of the patterns produce segments with the third

\section{A. commutatum 'Tricolor'}

\begin{tabular}{|c|c|c|}
\hline \multirow[b]{2}{*}{ A. nitidum 'Ernesto's Favorite' } & MREC 277028 & \multirow[b]{3}{*}{ 'Golden Bay' } \\
\hline & \multirow[b]{4}{*}{ MREC 1501} & \\
\hline \multirow[b]{2}{*}{ A. commutatum 'Tricolor' } & & \\
\hline & & \\
\hline & & \\
\hline Aglaonema 'Manila' & & \\
\hline
\end{tabular}

Fig. 1. Pedigree of Aglaonema 'Golden Bay'.

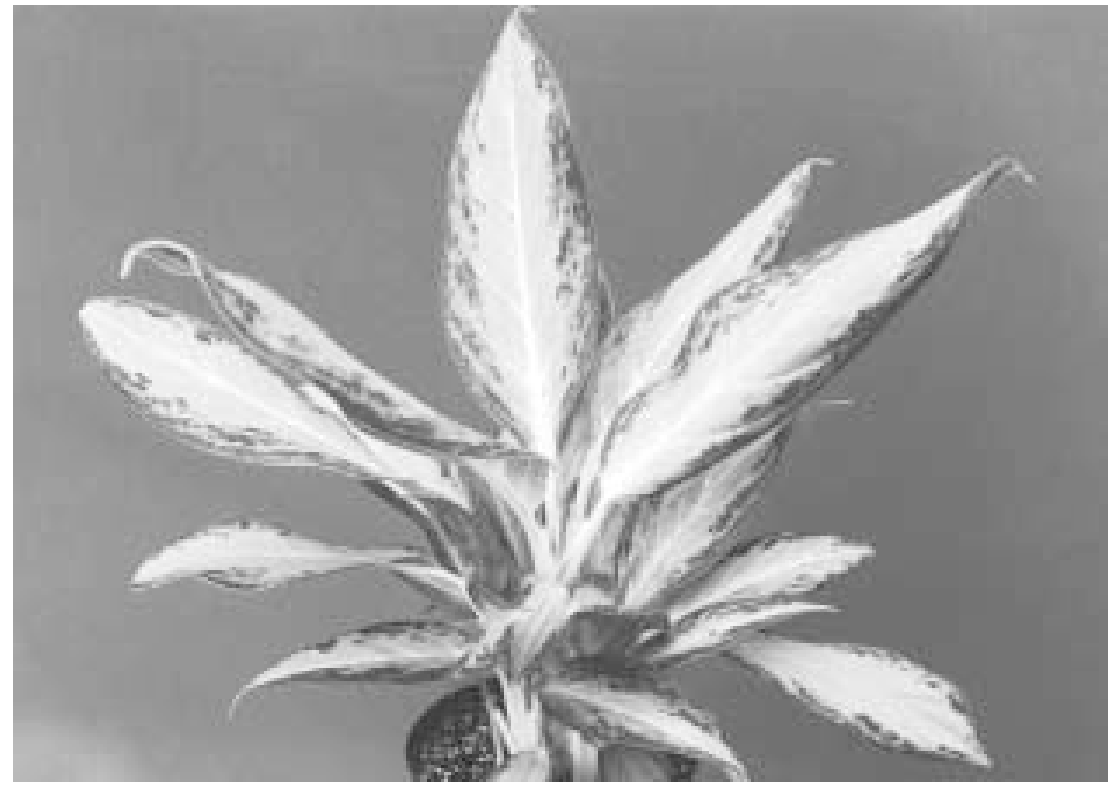

Fig. 2. A 7-month-old plant of Aglaonema 'Golden Bay’ in a 1.6-L pot.

Table 1. Size of Aglaonema 'Golden Bay' grown at three nutritional levels for 10 months (November to October).

\begin{tabular}{lccccccc}
\hline Fertilizer $(\mathrm{N})$ & $\begin{array}{c}\text { Canopy } \\
\text { per year }\left(\mathrm{g} \cdot \mathrm{m}^{-2}\right)\end{array}$ & $\begin{array}{c}\text { Canopy } \\
\text { width }\end{array}$ & $\begin{array}{c}\text { Pulled-up } \\
\text { height }\end{array}$ & $\begin{array}{c}\text { Leaf } \\
\text { length }\end{array}$ & $\begin{array}{c}\text { Leaf } \\
\text { width }\end{array}$ & $\begin{array}{c}\text { No. basal } \\
\text { shoots }\end{array}$ & $\begin{array}{c}\text { Visual } \\
\text { quality }^{\mathrm{z}}\end{array}$ \\
\hline 52 & 37.7 & 46.0 & 45.2 & 27.9 & 8.8 & 4.8 & 4.7 \\
104 & 34.5 & 42.6 & 42.2 & 26.2 & 8.8 & 4.3 & 4.2 \\
156 & 33.3 & 39.0 & 40.9 & 24.4 & 8.6 & 3.7 & 4.0 \\
Significance & $\mathrm{L}^{*}$ & $\mathrm{~L}^{*}$ & NS & L $^{*}$ & NS & NS & NS \\
\hline
\end{tabular}

${ }^{2}$ Visual quality where $1=$ poor, $2=$ fair, $3=$ saleable, $4=$ good and $5=$ excellent.

ss, "Nonsignificant and linear (L) significance at $P<1 \%$ level, respectively. 
in a completely randomized design. Data recorded at termination of the study included canopy height, canopy width, height with the leaves pulled up, length and width of largest leaf, number of basal shoots, and a visual quality rating where $1=$ poor; $3=$ acceptable (saleable); and $5=$ excellent quality. Data were analyzed using analysis of variance procedures of the SAS program (SAS Institute, Cary, N.C.). Parameters with means showing significant differences were subjected to regression analysis.

Aglaonema 'Golden Bay' reached marketable size in 10 months. Canopy height, width, and length all showed significant linear decreases as fertilizer level increased (Table 1). There was no significant difference in pulled up height, leaf width, number of basal shoots, or visual quality, although all declined at higher fertilizer levels. Plants were well branched, averaging over three to four basal shoots per plant. Plant quality averaged from good to excellent at all nutritional levels.

\section{Availability}

Aglaonema 'Golden Bay' is intended for commercial producers growing finished plants in 1.6- or 3.9-L containers. Patent rights were assigned to the Florida Foundation Seed Producers. Stock plants have been released to several Florida tissue culture labs for propagation and distribution. Inquiries regarding participating laboratories may be obtained by writing the Florida Foundation Seed Producers, P.O. Box 309, Greenwood, FL 32443. Plants for research purposes may be obtained directly from R.J.H.

\section{Literature Cited}

Henny, R.J. 1983. Flowering of Aglaonema commutatum 'Treubii' following treatment with gibberellic acid. HortScience 18:374.

Henny, R.J. 1985. In vivo pollen germination of Aglaonema affected by relative humidity. HortScience 20:142-143.

Henny, R.J. 1986. Single locus, multiallelic inheritance of foliar variegation in aglaonema. J. Hered. 77:214-215.

Royal Horticultural Society. 1995. The Royal Horticultural Society's colour chart. 3rd ed. Royal Hort. Soc., London. 